\title{
Transformational Leadership in Military Organization to Supporting National Defense Capability in Era of Industrial Revolution 4.0: A Literature Review
}

\author{
Dyah Anissa Rehardiningtyas ${ }^{1}$, Hikmat Zakky Almubaroq ${ }^{2}$ \\ ${ }^{12}$ Fakultas Manajemen Pertahanan, Universitas Pertahanan Republik Indonesia, Bogor \\ *Corresponding author, e-mail: dyahanissa88@gmail.com
}

\begin{abstract}
TNI as a means of state defence is who in charge to carrying out state defence to uphold state sovereignty, maintain territorial integrity, and protect the safety of the nation. For military organizations, leadership is the main thing needed, every military soldier is always ready to carry out orders from superiors, leadership attitudes to defend and develop themselves personally are very much needed both in everyday life or during combat. Transformational leadership is characterized by a leader working with subordinates to identify needed change, creating a vision to guide change through inspiration, and implementing the change together with committed group members. This study uses a descriptive qualitative approach as the main writing approach. The data used in this paper is secondary data. A transformational leader will be able to make positive changes in the organization. Transformational leadership in the industrial era 4.0 generates commitment from all stakeholders involved and increases the satisfaction and trust of everyone involved in the organization. The conclusion in the study: a good TNI leadership model is a transformational leadership model that emphasizes a leader motivating his subordinates to carry out responsibilities.
\end{abstract}

Keywords: Industry 4.0, Transformational Leadership, Military Organization

Received December 23, $2021 \quad$ Revised January 25, $2022 \quad$ Published Januari 31, 2022 author.

\section{Introduction}

Indonesian defense is structured in a universal defense system to achieve national goals. Universal defense is essentially a defense that involves all citizens according to their roles and functions. The involvement of every citizen is based on a love for their homeland which is oriented towards common goals in realizing the national interest. The conception of national defense becomes a guide for every citizen to be able to understand it as a form of; achievement of national goals; national interest; the nature of national defense; national defense system; national defense function; and the use of national defense components.

The national goals of national defense, as stated in the Preamble of Undang-Undang Dasar 1945, are to protect the entire Indonesian nation and the entire homeland of Indonesia, promote public welfare, educate the nation's life, participate in carrying out world order based on independence, eternal peace and social justice (Kementerian Pertahanan Republik Indonesia, 2014)

Efforts to realize and defend the entire territory of the Republic of Indonesia as a defense unit are carried out in the functions of deterrence, prosecution and recovery. The function of deterrence is a manifestation of the defense effort of all national forces which has a psychological effect to prevent and eliminate any threats, both from outside and arising within the country, to the sovereignty, territorial integrity of the Unitary Republic of Indonesia and the safety of the entire nation. In the face of military threats, the TNI as the main defense force is supported by the Reserve Components and Supporting Components through mobilization. 
The Indonesian National Army as a defense tool for the Unitary State of the Republic of Indonesia, has the task of implementing state defense policies to uphold state sovereignty, maintain territorial integrity, and protect the safety of the nation, carry out military operations for war and military operations other than war, and actively participate in regional peacekeeping tasks. and international. The TNI organization consists of the TNI Headquarters. The TNI is led by a Commander. The Commander is appointed and dismissed by the President after obtaining the approval of the House of Representatives. The appointment and dismissal of the Commander is carried out based on the interests of the TNI organization.

The Indonesian National Armed Forces (TNI) is an organization that instills pragmatic and structured values in the management of its human resources, although currently the TNI has carried out reforms within its organization. TNI in achieving its organizational goals, must be supported by human resources and the existence of a reformist leader who cares about change and can play an important role in the running of the organization. In accordance with its role, the leader is a direct setter, an agent of change, a negotiator (spokesperson), and as a coach in moving all components or organizational resources to achieve goals. Leadership is the most important factor in every organization. Its existence is very important because it is the key to the creation of success in the organization. The success and failure of an organization is largely determined by the quality of a leader. Likewise, the success and failure of an organization, both public and private, are usually perceived as the success and failure of leaders. For military organizations, leadership is the main thing that is needed, because every military soldier has gone through a selection to get the qualifications needed to always be ready to carry out orders from superiors, so that the spirit and attitude of leadership to maintain and develop themselves personally is very necessary both in daily life. -day or at the time of combat.

Based on previous research by Purnomo (2020) the result are the transformational leadership model makes subordinates being trusted, admired, loyal, and respectable to leader, so they are motivated to do what is hoped of them even give satisfaction to the Leader more than expected that subordinates are willing to sacrifice himself. In this study, the human dimension in the industrial revolution 4.0 prioritizes by analyzing transformational leadership theory which focuses on the study of the specific behavior of a military leader (leader behavior is a predictor of leadership influence and is the best determinant of leadership success). According to the world's leading consultant Deloitte, Industry 4.0 is able to increase the level of military operational readiness. In Sarjito (2019) The era of the industrial revolution 4.0 has an impact on leadership styles. Traditional military leadership which tends to be rigid and stagnant is no longer appropriate to be applied. Advances in Industry 4.0 technology greatly help national defense organizations improve their readiness and effectiveness.

Leadership is one of the issues in management that is still quite interesting to be discussed today. The mass media, both print and electronic, often present opinions and talks about leadership. The very strategic and important role of leadership in achieving the mission, vision, and goals of the organization, is one of the motives that encourage people to investigate deeply related to leadership. Apart from that, the leader also plays a very important role in the growth and development of organizational culture in the organization. The good and bad of an organization depends on the conditions or organizational climate created by its leaders which will later form into an organizational culture in it (Permana, 2021).

Leadership style can facilitate change, increase work commitment and improve overall organizational performance and approach within the organization. Transformational leadership is a leadership style that is suitable for today's situations. Transformational leadership is characterized by a leader working with subordinates to identify needed change, creating a vision to guide change through inspiration, and implementing the change together with committed group members. In making decisions, it is indeed the authority of a commander as a decisions maker and decisions are made based on considerations, suggestions and input from staff or assistant elements. 


\section{Literature Review}

\section{Leadership}

Leadership is the art of motivating a group of people to act towards the achievement of a common goal. This definition of leadership includes important things that can inspire others and are prepared to do so. Effective leadership is based on ideas (either original or borrowed), but those ideas will not materialize without being communicated to others by engaging them to act as the leader wants them to be.

According to Harsey and Blanchard in Hendrawan et al., (2020), leadership is the process of directing and influencing the task-related activities of a group members. illustrates that a leader must try to optimally move subordinates, so that they can work together productively to achieve goals. Leadership is an important factor in organizational life, because the ability of a leader to influence his employees is a factor that determines the success or failure of an organization. A leader must be able to develop strategies to influence subordinates as desired by the organization.

In leadership theory it is explained that a person is called a leader if he is able to influence others to do something according to what he wants. Effective leadership is leadership that emphasizes the behavior of the leader rather than the characteristics of the existing leader. The leader's role is expected to act effectively as a leader. When leaders feel energized, enthusiastic, and active they are more likely to energize their subordinates and convey a sense of effectiveness, competence, optimism and excitement, leadership is influence, the ability to gain followers, and being someone others follow with pleasure and confidence.

Leadership is also a driver for the resources and tools owned by the company. The definition of leadership, according to Terry, "Leadership is the activity of influencing people so that they like to try to achieve group goals" (Hendrawan et al., 2020). The results of the author's review reveal that management writers agree that leadership is a process of influencing the activities of a person or group of people to achieve goals in certain situations. According to Ordway Teod in his book The Art of Leadership, "Leadership is the activity of influencing people to work together to achieve the goals they want. It can be concluded that leadership is the ability to influence subordinates or a group of people to work together to achieve organizational goals.

\section{Transformational Leadership}

Transformational leadership can create something new from something old. According to Avolio \& Bruce in Susiawan \& Muhid (2015), the practice of transformational leadership style is able to bring about more fundamental changes such as changes in the values, goals, and needs of subordinates. Transformational leadership in the organizational context by Bernard Bass is the ability of leaders to change the work environment, work motivation, and work patterns, and work values perceived by subordinates so that they are better able to optimize performance to achieve organizational goals. Transformational leaders seek to transform visionary into a shared vision so that they (subordinates and leaders) work to make the vision a reality (Adinata, 2015).

Transformational leaders pay attention to each member, try to understand their needs, and provide emotional support when they feel frustrated at work (Rusdiyanto \& Riani, 2015)This increases members' feelings of security and encourages them to be confident in the tasks assigned to them. Previous research has argued that transformational leadership can increase supervisors' perceptions of support (Liaw et al., in Lai et al., 2020). This individualized consideration may make members feel psychologically secure and increase their willingness to be fully engaged in the workplace (Anderson, 2017).

According to Bass \& Avolio (1990), there are 4 elements that underlie transformational leadership, namely:

1. Idealized Influence, a transformational leader gets his charisma from the views of followers, a charismatic leader will have a lot of influence and can move his subordinates. 
2. Inspiration motivation, an inspirational leader can articulate common goals and can determine an understanding of what is felt to be important and what feels right.

3. Intellectual stimulation, leaders are required to be able to help their subordinates be able to rethink old problems with new methods and ways.

4. Individualized consideration, a leader must be able to treat his subordinates differently but fairly and provide infrastructure in order to achieve goals and provide challenging work for subordinates who like challenges.

According to Yulk (Anggraeni \& Santosa, 2013) there are several things concerning transformational leadership, namely:

1. Work Motivation, motivation is a process by which one's work behavior is energized, directed and maintained in work and organizational life.

2. Organizational Commitment, transformational leadership has a direct effect on their support, commitment, and involvement in organizational change through charisma behaviors, articulation of vision and emphasis on individual attention

3. Job Satisfaction, the behavior of transformational leaders is due to one aspect of job satisfaction is supervision. Supervision provided by the leader through individual attention, and inspirational motivation members of organization to do a good job.

\section{Transformational Leadership in Era of Industrial Revolution 4.0}

Transformational has a vision of the future and is able to identify environmental changes and be able to transform these changes into the organization (Sukmana \& Sudibia, 2015). Transformational leadership is needed in developing military organizations in the era of the industrial revolution 4.0. The Commander in Chief as the leader of the military organization is required to be able to transform the work climate and adjust the development of defense equipment and technology for the advancement of the TNI as a military organization he leads. Through transformational leadership, leaders try to mobilize human resources in the organizational environment to innovate in the work process. The ability of leaders to mobilize soldiers to take advantage of digital technology that will be very useful so that it affects the achievement of military organization goals.

Transformational leadership in the industrial era 4.0 is carried out through the activities of a leader through improving organizational performance, generating commitment from all stakeholders involved and increasing the satisfaction and trust of everyone involved in the organization. The success of transformational leadership is largely determined by human resources through various holistic efforts. The commitment of all organizational stakeholders is very important in the era of the industrial revolution 4.0.

The progress of science and technology in the era of the industrial revolution 4.0 has a significant impact on changes in the way of thinking and working. The industrial revolution 4.0 is an unavoidable combination of humans and technology. This is where the role of the leader is required to be able to continue to make changes for the better. As a leader, he is expected to be able to carry out his duties well and make changes through his leadership by utilizing all the potential and abilities possessed by existing human resources. Transformational leadership can be a solution to keep up with developments in the era of the industrial revolution 4.0 by utilizing information and communication technology in the development of digital-based education. However, leaders will not be able to work alone, therefore the support of organizational members is needed to jointly develop education in the era of the industrial revolution 4.0 .

\section{TNI as Military Organization}

TNI is lead by a Commander who is appointed by the President based on the interests of the TNI organization. The duties and obligations of the Commander in Chief based on Pasal 15 Undang-Undang Republik Indonesia No. 34 of 2004 (Indonesia, 2004), namely; lead the TNI; implement national defense policies; carry out military strategy and carry out military 
operations; develop TNI doctrine; carry out the use of the TNI's power for the benefit of military operations; carry out the development of the TNI's strength and maintain operational alertness; give consideration to the Minister of Defense in determining the national defense policy; give consideration to the Minister of Defense in determining policies to meet the needs of the TNI and other defense components; give consideration to the Minister of Defense in preparing and implementing strategic planning for the management of national resources for the benefit of national defense; using reserve components after being mobilized for the benefit of military operations; using supporting components that have been prepared for the benefit of military operations; and carry out other duties and obligations in accordance with the laws and regulations.

The leadership model in the military perspective in a country is leadership that has close links and tendencies to leadership practices that apply principles, values, ideologies, discourses and military behavior which include commando, hierarchy, discipline, uniformity, and others. The state leadership is under the authority and interests of the domination of military institutions (military institutions) and/or the state that uses strong disciplinary principles in the administrative process, either directly or indirectly.

\section{Method}

This article was compiled based on a literature study using a descriptive qualitative approach as the main writing approach. The data used in this paper is secondary data, where secondary data is generally in the form of evidence, records, or historical reports that have been compiled in archives (documentary data), both published and unpublished.

The techniques used to collect data in this paper are: (1) Literature study, The study of literature and data sources in this study was carried out by searching and studying various literatures, scientific articles, both in the form of books, journals and statutory documents related to Transformational Leadership (2) Documentary, the study of documentation is done by reading reports of previous writings and journals related to this writing. In this method, the writer only moves the relevant data from the source or the required document; (3) Discussion, collecting data by discussing ideas with competent people in this regard to solve certain problems related to this paper; and (4) Intuitive-Subjective, is the involvement of the author's opinion about the problem being discussed.

\section{Results and Discussion}

This paper is a development of several previous research results such as the one written by Kristanto Setio Hari Purnomo with the title Leadership Model in a Transformational Perspective Military Organization which wrote that the transformational leadership model is able to make subordinates obedient, obedient, and loyal to their leaders. Leadership in the TNI is called field leadership which was adopted from the Great General Panglima Sudirman, which is described in 5 leadership models, namely: Leaders as fathers, coaches, friends, teachers, and commanders. The identity of the TNI which includes the soul, spirit and driving force from within is shown through the process of national struggle in which the TNI is part of the people, is born, and struggles with the people to defend the interests of the state.

Leadership style is a behavioral norm that is used by someone to try to influence the behavior of others as he wants. The leadership style in the organization is needed to develop a conducive work environment and build a motivational climate for employees so that it is expected to produce high productivity. Transformational leaders not only entertain members when faced with challenging tasks but also enhance problem-solving abilities. That is, transformational leaders use intellectual stimulation to encourage members to increase productivity and conserve resources (eg, energy). Thus, transformational leaders encourage members to effectively use their intelligence or experience, see problems from multiple angles, master the problem-solving process, and determine the best solutions to increase efficiency. This implies that leaders can offer sufficient resources (e.g. physical, emotional, or psychological) to members to try new solutions to task-related problems. This may result in psychological availability and increase the work of attachment members. 
The difference between the leadership of military organizations and non-military organizations is that military organizations have systems and procedures that are better and more complex than non-military or civilian organizations, and all obey the command of the highest superior, in this case the highest leadership, namely the TNI Commander. Field Leadership based on the manuscript of the Department for Dikmaba Students 2010 is described in a complex manner in every aspect of the movement of leaders in military organizations or the TNI. The manuscript describes all aspects of field leadership. A leader with a transformational model will be able to be able to make positive changes in the organization, namely being able to make his subordinates admire, respect and trust him at the same time, inspire motivation and inspire his subordinates, provide creative solutions to problems faced by subordinates, willing to listen attentively to input. -subordinate input and specifically want to pay attention to the needs of subordinates.

Previous research written by Aris Sarjito entitled Digital Military Leadership Model in the Industrial Revolution Era 4.0 stated that the industrial revolution era 4.0 had an impact on leadership style. Transformational leadership in the industrial era 4.0 is carried out through the activities of a leader through improving organizational performance, generating commitment from all stakeholders involved and increasing the satisfaction and trust of everyone involved in the organization. The industrial revolution 4.0 is an unavoidable combination of humans and technology. This is where the role of the leader is required to be able to continue to make changes for the better.

The role of leadership in facing challenges in the era of the industrial revolution 4.0 can at least be done through a transformational leadership model. The transformational leadership model requires organizations to be able to collaborate and utilize all of their abilities to see and anticipate technological advances through a series of managerial activities to prepare human resources and facilities that support the educational process in the era of the industrial revolution 4.0 (Prestiadi, Gunawan, \& Sumarsono, 2020). The role of transformational leadership as an agent of change in an organization. Transformational leadership seeks to utilize existing human resources and increase the commitment of all stakeholders of educational institutions to be very important in the era of the industrial revolution 4.0.

As a military organization, a bold and decisive way of leading is needed, but it turns out that the authoritarian leadership model is not suitable to be applied in the TNI. The TNI leader, known as the TNI Commander, must also be able to position members or subordinates flexibly, namely not merely as subordinates, but as work partners and executor of tasks. So that between subordinates and leaders there is no barrier that is too far away and the leader always sets an example. For example, if the members carry out a task that cannot be completed by themselves, the leader goes directly to the field to help them.

Transformational leaders are charismatic leaders and have a central and strategic role in bringing the organization to achieve its goals. Transformational leaders must also have the ability to match the vision of the future with their subordinates, and heighten the needs of subordinates at a higher level than what they need. Transformational leadership is leadership that really works towards goals in the act of directing the organization to a goal that has never been achieved before. Real leaders must be able to direct the organization in a new direction. Transformational leadership involves change in the organization that requires action to motivate subordinates to be willing to work for high-level goals that are considered to be beyond their personal interests at the time.

In non-war conditions, within units within a military organization, an organizational leader can use transformational leadership in making decisions and in carrying out his duties as a leader. Making decisions, it is indeed the authority of a commander as a decisions maker and decisions are made based on considerations, suggestions and input from staff or assistant elements. However, this can be adapted to tasks and jobs that require a command system. Different with the types of tasks that require collaboration or integration with other parties. A good TNI leadership model is a transformational leadership model, because in TNI it emphasizes a leader needs to motivate his subordinates to carry out their responsibilities more than they expect, not just carry out orders. Transformational leaders are able to define, 
communicate and articulate the vision of the organization, and subordinates must accept and acknowledge the credibility of the leader. This, transformational leadership is one of the excellent leadership models to be applied by military organizations in the era of the industrial revolution 4.0 .

\section{Conclusion}

In military organizations, all obey the command of the highest superior, in this case the highest leadership, namely the TNI Commander. The Commander in Chief as the leader of a military organization is expected to be able to carry out his duties properly and make changes through his leadership by utilizing all the potential and capabilities of existing human resources. Through transformational leadership, leaders can be a solution to follow developments in the era of the industrial revolution 4.0 by utilizing information and communication technology in the development of a digital-based military world. However, leaders will not be able to work alone, therefore the support of all members of military organizations is needed to jointly develop in the era of the industrial revolution 4.0.

Transformational leadership is leadership that changes the energy of resources and situations to achieve goals. Transformational leadership traits are charismatic, inspiring, stimulating, individually considerate. A good TNI leadership model is a transformational leadership model, because in TNI it emphasizes a leader needs to motivate his subordinates to carry out their responsibilities more than they expect and not just carry out orders. The transformational leadership model is appropriate to be applied in military organizations.

\section{References}

Adinata, U. W. S. (2015). Pengaruh Kepemimpinan Transformasional, Motivasi, dan Budaya Organisasi Terhadap Kinerja Karyawan KJKS BMT Tamzis Bandung. Jurnal Ekonomi, Bisnis \& Entrepreneurship, 9(2), 136-157.

Anderson, M. (2017). Transformational Leadership in Education: A Review of Existing Literature. International Social Science Review, 93(1), 4.

Anggraeni, Y., \& Santosa, T. E. C. (2013). Pengaruh Kepemimpinan Transformasional Terhadap Kepuasan Kerja Karyawan. Jurnal Dinamika Ekonomi \& Bisnis, 10(1), 51-68.

Bass, B. M., \& Avolio, B. J. (1990). Developing Transformational Leadership: 1992 and Beyond. Undefined, 14(5), 21-27. https://doi.org/10.1108/03090599010135122

Hendrawan, A., Laras, T., Sucahyowati, H., \& Cahyandi, K. (2020). Peningkatan Kepemimpinan Transformasional Dengan Organizational Citizenship Behavior (Ocb). Jurnal Bidang Sosial Humaniora Dan Ekonomi, 1(1), 78-89.

INDONESIA, S. N. R. (2004). Undang undang no 34 tahun 2004 tentang TNI. (1), 1-42.

Kementerian Pertahanan Republik Indonesia. (2014). Buku Putih Pertahanan Indonesia.

Lai, F. Y., Tang, H. C., Lu, S. C., Lee, Y. C., \& Lin, C. C. (2020). Transformational Leadership and Job Performance: The Mediating Role of Work Engagement. SAGE Open, 10(1). https://doi.org/10.1177/2158244019899085

Permana, D. (2021). Model Kepemimpinan Masa Depan Indonesia Dalam Perspektif Sipil Dan Militer. Jurnal Academia Praja, 4(1), 277-294.

https://doi.org/10.36859/jap.v4i1.394

Prestiadi, D., Gunawan, I., \& Sumarsono, R. B. (2020). Role of Transformational Leadership in Education 4.0. 501(Icet), 120-124. https://doi.org/10.2991/assehr.k.201204.020

Purnomo, K. (2020). Model Kepemimpinan Pada Organisasi Militer Perspektif Transformasional (Studi Pada Tentara Nasional Indonesia: Resimen Induk Komando Daerah Militer VI Brawijaya, Jawa Timur). 1-12. 
Rusdiyanto, W., \& Riani, A. L. (2015). Pengaruh Kepemimpinan Transformasional Dan Transaksional Terhadap Kepuasan Kerja Dan Organizational Citizenship Behavior. Jurnal Econimia, 11(2), 161-168.

Sarjito, O. A. (2019). Model Kepemimpinan Militer Digital Di Era Revolusi Industri 4.0. Manajemen Pertahanan, 5(2), 49.

Sukmana, E., \& Sudibia, G. (2015). Pengaruh Kepemimpinan Transformasional, Motivasi Dan Burnout Terhadap Kinerja Karyawan Outsourcing Rri Mataram. E-Jurnal Manajemen Universitas Udayana, 4(8), 255319.

Susiawan, S., \& Muhid, A. (2015). Kepemimpinan Transformasional, Kepuasan Kerja dan Komitmen Organisasi. Persona:Jurnal Psikologi Indonesia, 4(03), 304-313. https://doi.org/10.30996/persona.v4i03.725 